\title{
The Effect of Guilt on Post-Purchase Regret: Attitudes and Repurchase Intentions Towards Smoking
}

\author{
Ijpek KAZANCOGLU1 $\odot$, Hatice AYDIN² $\odot$, Atul MISHRA ${ }^{3} \odot$
}

\begin{abstract}
The aim of the study is to analyze the effect of smokers' guilt on regret and the effect of regret on attitudes and repurchase intention towards tobacco smoking. In addition, it is aimed to determine whether attitudes have a mediating effect on the relationship between regret and repurchase intention towards smoking. Face-to-face survey is conducted to collect data with 429 tobacco smokers in Izmir-Turkey by judgment-sampling method. The findings showed that the post-purchase guilt felt by consumers in terms of health, financial and moral guilt resulted in a feeling of regret. Regret was also found to affect repurchase intention due to the mediating effect of attitudes towards smoking. Another finding also displays that, despite the sample of consumers' represent negative attitudes, they could still exhibit repurchase behavior towards tobacco smoking. The contribution of this study is to investigate guilt and regret simultaneously, to reveal their effects on attitudes and, repurchasing intention towards smoking within the context of social marketing.
\end{abstract}

Key words: Regret, Guilt, Attitudes towards Smoking, Repurchase Intention

\section{INTRODUCTION}

Tobacco is a substance that can lead to psychological and physical addiction and harm society's economic and social welfare. Nicotine in tobacco is known to cause both physical and psychological addiction (conditioned pleasure and delight), thus smoking is considered by the medical world as a chronic health problem that can be contagious (Ozlu, 2008; Ozcan et al., 2013; Wymer, 2015). Additionaly, smoking is perceived as an immoral behavior for women in Asian and Middle East countries such as Korea, India, Pakistan, Turkey (Dagli, 1999; Kim and Shanahan, 2003; Ganatra et al., 2007; Ra and Cho, 2018). There are studies reporting that 1.2 billion people over age 15 around the world smoke, $80 \%$ from developing countries (Rahman et al., 2018). In Turkey more than 100,000 people die each year due to diseases related to tobacco use (Turkish Ministry of Health, 2018). The number of annual tobacco deaths is estimated to rise to 10 million by 2030 in worldwide if precautions are not taken (World Bank Tobacco Report, 2019). According to World Health Organisation (WHO) statistics 2019, the ratio of daily smokers in Turkey fell from $32 \%$ in 2000 to $26.5 \%$ of population aged $15+$ in 2018 . However, Turkey has the second highest smoking rates in the OECD countries after Greece (OECD Health Statistics, 2019). Considering that around 100,000 people die due to tobacco-related causes in Turkey and the age of smoking initiation is 10-11 in 2015, combating the "smoking habit" can be said to be one of the most important issues (Kayli and Yararbas, 2016). The most important reason for the increasing rate especially among the young consumers' is thought to be the insensitivity to increasing prices (Wymer, 2015). Moreover, due to shortcomings, such as inefficient local public control over smoking and inefficient implementation of anti-smoking acts, smoking rates started to increase again after 2012 (Uzundumlu and Topcu, 2015). Despite the criticism and local public control, the consumers continue to smoke and have their own motives i.e., to achieve happiness (Dawkins et al., 2007) and pleasure (Vieira, 2014; Wymer, 2015; Carneiro et al., 2017), to eliminate anxiety and stress (Patten et al., 2018), to control weight (Carneiro et al., 2017) and to share common interest with friends (Wymer, 2015). These

${ }^{1}$ Associate Prof. Dr., Ege University, Department of Business Administration, ipek.savasci@ege.edu.tr

${ }^{2}$ Associate Prof. Dr., Bandirma Onyedi Eylül University, Applied Science, haydin@bandirma.edu.tr

${ }^{3}$ Dr., University of Plymouth, Plymouth Business School, PL4 8AA, United Kingdom, atul.mishra@plymouth.ac.uk 
perceived benefits are probably reasons for prevalences of the consumption of tobacco and tobacco products among different age groups. According to an estimate, by the end of $2015,21 \%$ people were smoking on a regular basis with $28 \%$ as the highest rate of smoking among adults in Europe (World Health Organization, 2015). The situation was not much different in Turkey where heavy smokers were 27.2\% (Eurostat, 2015).

Smoking is an addictive behavior that causes a leading and major public health problem in the world. For this reason, social marketing designs campaign strategies and policies to cope with the consumption of this unhealthy and harmful product in order to encourage and support changes in attitudes and behaviors (Sampogna et al., 2017). Carneiro et al. (2017) indicated that social marketing has influenced target markets to accept a new behavior, modifying current behavior or abandoning an unwanted habit. Therefore, social marketing activies are needed to reduce or change smoking behavior. Although the legal improvements and public awareness programs have to restrict the consumption of smoking, a desirable reduction in consumption has not been achieved. In the field of social marketing, studies are carried out to identify and cope with environmental factors that trigger the buying impulses of smokers (Burton and Nesbit, 2015).

Smoking does not only provide a self-control mechanism on its own, as smoking results in bad social and personal outcomes, addressing it is a priority. Tobacco purchase and consumption may become a behavior that causes consumers to regard themselves negatively, or have negative feelings such as regret and guilt (Burnett and Lunsford, 1994). The feelings of guilt and regret are also few outcomes of smoking. The emotion of guilt among individuals is due to the negative assessments of their own behavior (Tracy and Robins, 2007). The consumption of tobacco triggers feeling of guilt in terms of health, financial and moral guilt to drive regret (Moan and Rise, 2005). However, some consumers may not be able to control their purchase, even though they feel regret and exhibit repetitive purchase behaviors (Passyn and Sujan, 2006). Taylor et al. (2006) presented that $83 \%$ of smokers feel regret for this habit and around three-quarters are trying to quit. This entails that smoking eliminates self-control as smokers engage in a behavior that is conflicted with their own attitude (Lerbin, 2015). People feel cognitive dissonance, but they tend to lose control which is one reason why they are unable to quit smoking despite their acknowledgement that it is harmful (Fong et al., 2004). Although smoking leads to unfavorable outcomes such as guilt and regret, it is seen as a type of addiction. Hence due to smoking addiction they feel regret and may have negative attitudes towards tobacco but continue to consume. The consumers'smoking behaviors or habits can be explained by cognitive dissonance theory (Baumeister, 2017).

The aim of this study is to investigate the effect of smokers' guilt on regret and the effect of regret on attitudes and repurchase intention. In addition, the objective of the paper is to determine whether attitudes have a mediating effect on the relationship between regret and repurchase intention towards smoking. This research contributes examining the relationship between guilt and regret arising from tobacco consumption. For this purpose, the study sample consisted of regular smokers aging 18 years and above in Izmir, third largest province of Turkey. Initially, in this study, theoretical background and guilt and regret are investigated. The second part explains the literature review along with the research model and hypothesis development. The third part gives details about methodology and findings of this research. The fourth part put forth the discussion and the conclusion. The last section, theoretical contribution and managerial implications, limitation and future research are discussed.

\section{THEORETICAL BACKGROUND}

Smokers continue to smoke even though they know its harmful health effects (Fong et al., 2004). This situation causes psychological discomfort and evokes negative emotions such as bad, miserable, regret and guilt due to smoking (Sweeney et al., 2000). It is thought that smoking consumption reflects a cognitive dissonance (Fotuhi et al., 2013) and attitudes towards consumption affect behavioral intentions (Lerbin, 2015). The Cognitive Dissonance Theory (CDT) provides a theoretical basis to examine consumer emotion of guilt arising out of smoking with its role in triggering the feeling of regret among Turkish smokers. CDT is developed by Festinger (Festinger, 1957) that provides a theoretical basis from which to investigate the effect of guilt felt after smoking on the feeling of regret, and the effect of regret on attitudes and repurchase intention. The theory posits that in cases where two cognitive elements are in opposition, cognitive dissonance occurs-creating pressures within a person to reduce dissonance through misperception or misinterpretation of the information or by ignoring it completely (Peretti-Watel, 2006; Fotuhi et al., 2013; Ozbas et al., 2018). 
This theory has been applied to different contexts and situations, especially to the study of addictive behaviors i.e., tobacco consumption. When smokers understand that smoking cause diseases such as cancer then they change their behaviors by stopping smoking or by denying the dangerous effects of smoking (Metin and Camgoz (2011). The theory provides framework for understanding inconsistencies among consumers who understand the harmful effects but continue to smoke despite feeling guilt and being regretful (Ozbas et al., 2018). In contrast to non-smokers, smokers use rationalization through supporting more functional beliefs (i.e., smoking helps me concentrate better and enjoying the biological effects of smoking), risk reduction beliefs (i.e., thinking that the medical evidences implying the harmful effects of smoking are exaggerated) and ignoring the harmful effects (i.e. smoking is not really harmful for me) (Nayak et al., 2017; Bice, 2018). In this way, smokers rationalize the smoking behavior and get out of psychological disturbances that are brought about by inconsistent thoughts (Orcullo and San, 2016). Consumers feel regret due to smoking attitudes; however it does not negatively affect their attitudes and their consumption behaviors. Hence, in this regard they admit experiencing cognitive dissonance (Fong et al., 2004; Ozbas et al., 2018).

There are studies in the literature that examine the feeling of guilt and regret (Brewer et al., 2016; Lee and Cotte, 2009). However, the studies concerning guilt related to smoking are rare (Netemeyer et al., 2016). Janjigian et al. (2010) reported that smokers experienced a stronger sense of guilt compared to non-smokers. Orcullo and San (2016) stated that smokers feel guilty in their behaviors or beliefs when it is regarded by the society as an undesirable and inconsistent action. Some studies explored the regrets of tobacco consumption using cross-country comparisons e.g. the result of a study showed that Thai smokers are more likely to regret compared to Malaysians (Lee, 2007).

The other studies investigated anticipated regret on smoking intentions. Anticipated regret moderates the relationship between purchasing intentions and smoking initiation (Conner et al., 2006). Anticipated regret is found to be a mediating variable between social norms and attitudes towards purchase intentions (Lazuras et al., 2012). Nayak et al. (2017) indicated several predictors of regret in smoking initiation i.e. intention and attempts to quit and being addicted to smoking and fear of smoking related illnesses. In this sense, both feelings are interrelated thus it is necessary to evaluate them together.

\section{GUILT AND REGRET}

Guilt is related to private moral obligation towards others (Baumeister et al., 1994; Lancellotti and Thomas, 2018). This emotion occurs when individuals violate ethical rules (lying, stealing, etc.), environmental friendliness issues (Sirieix et al., 2017), give up dieting, consume harmful products (tobacco, alcohol, etc.), indulge in excessive eating (Ruddock and Hardman, 2018) and purchase of expensive luxury products (Lyons et al., 2019).

Regret is generally defined as an emotional situation that causes feelings of suffering and sadness due to misfortune, limitations, loss, deficiencies, or mistakes (Patrick et al., 2009). It can also result from moral violation of law (Imhoff et al., 2012). The individuals compare the choices among alternatives and feel uncomfortable, believing they chose the wrong alternatives. In marketing concept regret is a negative emotion elicited either by an unnecessary purchase, or missing opportunities, despite having purchasing power (Lee and Cotte, 2009) and it is acknowledged as a bridge between decision to purchase and non-purchase (Tsiros and Mittal, 2000; Dedeoglu and Kazancoglu, 2012). The consumers feel regret when they believe they chose the wrong alternative. The consumers perceive some risks which are linked to guilt and then feel regret after buying (Lee and Cotte, 2009). The researcher (Bathaee, 2013) recently identified various types of regret which involved negative emotions such as discomfort and pessimism. Regret is different from guilt. According to Ben-Ze'ev (Ben-Ze'ev, 2000), "when we did something that is forbidden, we feel guilt; when we did something that is a failure, we feel regret". This is to say that regret is the stronger feeling than guilt (Roseman, 1991) and reflects different psychological processes (Brewer et al., 2016). Guilt can be strongly related with interpersonal emotions that arise in social relationships, but regret is associated with intrapersonel emotions (Wagner et al., 2012). While guilt results from doing something that consumer considers as morally or legally wrong, regret is felt by learning that consumer could have done something different or better (Lyons et al., 2019). In this way, cognitive dissonance is evoked by feelings of regret (Penz and Hogg, 2011).

\section{HYPOTHESIS DEVELOPMENT}

The research model is presented as Figure 1. 


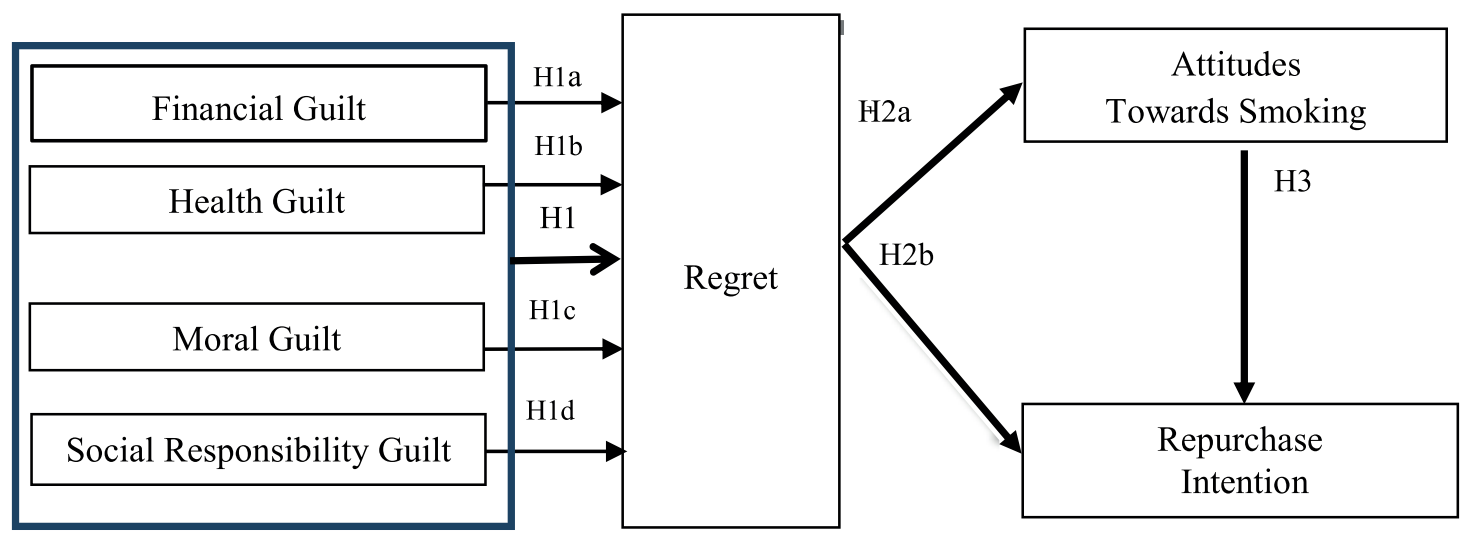

Figure 1: Research Model

In the direction of the model mentioned, the hypotheses are presented as below.

H1: Consumer guilt has a positive effect on regret.

H1a: Consumers' financial guilt has a positive effect on regret.

H1b:Consumers'health guilt has a positive effect on regret. H1c:Consumers' moral guilt has a positive effect on regret. H1d:Consumers' social responsibility guilt has a positive effect on regret.

H2a: Consumer regret has a negative effect on attitude.

$\mathrm{H} 2 \mathrm{~b}$ : Consumer regret has a negative effect on repurchase intention.

H3: Attitudes towards smoking has a positive effect on repurchase intention.

H4:Attitudes towards smoking has a mediating role on the effect of regret on repurchase intention.

\section{THE EFFECT OF GUILT ON REGRET}

Guilt is defined as violations of moral obligations or personal and social rules (Buchanan et al., 2016; Arli and Leo, 2017). The consumers' guilt causes regret (Wong and Kwong, 2007) which includes both interpersonal and intrapersonal features of guilt (Zeelenberg and Breugelmans, 2008). Indeed, according to Solomon, regret is an effective way to avoid guilt. Regret consists of guilt. Thus, smokers' major concern is nicotine dependence (Carneiro et al., 2017) and feeling regret at not being able to quit (Katajavuori et al., 2002). In addition, smokers may feel guilty when they recognize health and social consequences of smoking (Dijkstra et al., 2008). Smokers are worried that smoking is damaging to health and regret excessive spending on tobacco. Also, social approvals, norms and violating moral standards are significant predictors of regret.

Guilt is explained as financial, health, social responsibility and moral guilt (Saintives and Lunardo, 2017). The financial guilt is felt as a result of unnecessary and unplanned purchases, excessive spending, or purchasing without negotiating price (Burnett and Lunsford, 1994). Health guilt exists when a person purchases a product that is harmful to health. This type of guilt often arises due to the consumption of fattening foods, fast-food and frozen foods, all of which may be considered unhealthy (Burnett and Lunsford, 1994). These researchers also found that harmful effects of tobacco smoke can cause health guilt for consumers, as it affects their own health as well as the health of others. Moral guilt occurs as a result of purchases that violate moral standards, and when one has engaged in behaviors that are generally considered inappropriate by a society. Alcohol, sexually explicit materials, or non-prescription drugs are generally viewed morally wrong (Burnett and Lunsford, 1994). The tobacco smokers feel guilty, as they may disturb non-smokers and violate social norms (Poutvaara and Siemers, 2008). The social responsibility guilt is experienced when individuals exhibit behaviors unacceptable to others. In consumer context, this type of guilt arises when consumers are violating social obligations due to their purchase decision.

Therefore, making purchases that cause environmental pollution, or reduce the ability to make charitable donations or provide financial support to one's family may all cause social responsibility guilt (Burnett and Lunsford, 1994). The financial, health, moral and social responsibility guilt would diminish consumer's positive response, and may cause regret (Shiffman and Paty, 2006).

\section{THE EFFECT OF REGRET ON ATTITUDES}

Consumers' emotional states are influenced by their purchase attitudes and intentions (Bee and Madrigal, 2013) therefore, regret affects attitudes and intentions (Tsiros and Mittal, 2000). Smokers' regret is strongly 
associated to their attitudes and behavior (Sansone et al., 2013). Consumers consider the negative anticipated feelings, they may experience as a result of their unethical behavior, and this reduces the intention of the consumer to realize the action (Steenhaut and Van Kenhove, 2006). Therefore, the feeling of regret after smoking affects consumers' attitudes and preferences (Conner et al., 2006).

\section{THE EFFECT OF REGRET ON REPURCHASE INTENTION}

Simonson (1992), Abendroth (2000), Tsiros and Mittal (2000) explained that the feeling of regret had a positive effect on complaint and brand change behaviors, but negative effect on word of mouth communication (Uygur and Küçükergin, 2013), and repurchase intention. Patrick et al. (2003) also found that regret for purchases was more common than regret for non-purchases. Lee and Cotte (2009) investigated the factors that lead to post-purchase regret and found that customers experience two types of regret, i.e. they regret the things that they bought (outcome) and the way that they bought them (process). They also indicated that consumers face outcome regret because of alternatives that were not purchased, and process regret due to ignored or excess concentration during purchases. With regret, consumers may find their purchase decisions illogical, blaming themselves and are unable to defend this purchase decision (Inman and Zeelenberg, 2002). These emotions guide the thoughts and behaviors of consumers and cause individuals to have negative attitudes towards their future purchase behaviors (Lu et al., 2012) or repurchase intentions. The feeling of regret after smoking reduces their repurchase intentions towards smoking.

\section{EFFECT OF ATTITUDES ON REPURCHASE INTENTION}

Attitudes are related to behavioral intentions (Fishbein, 1975). According to Theory of Reasoned Action (TRA), attitude influences repurchase intentions of the same products (Fishbein and Ajzen, 1975; Ünal et al., 2019). The consumers'smoking attitudes are shaped by beliefs during the learning process (Bee and Madrigal, 2013). Therefore, they may develop a negative attitude to smoking. Moreover, as consumers develop awareness of health, they may also develop negative attitudes to the goods that are harmful to their health (i.e., tobacco, fatty and high-cholesterol foods) and begin to avoid them (Luchs and Mick, 2018). The stronger smoking intentions are associated with attitudes (Conner et al.,
2006) therefore repurchase intention can be said to depend on theses attitudes (Lerbin, 2015).

\section{MEDIATING EFFECT OF ATTITUDES}

Cognitive dissonance is defined as the psychological distress experienced after the purchase decision (Sweeney et al., 2000). In this sense, dissonance refers to negative feelings, such as the uncertainity resulting from a behavior and feelings of anxiety and regret. The cognitive dissonance is related to attitude and negatively affects customers' attitude when purchasing a product (Keng and Liao, 2009). According to some researchers, cognitive dissonance may either indirectly influence repurchase intention or it may be mediated by attitude. Regret is a type of dissonance and is associated with the action tendencies (Greenwald and Ronis, 1978). Regret may not directly influence consumers'intentions but the effect may also be fully mediated by other factors such as attitude (Lee, 2007). In other words, attitudes may mediate the effect of regret on repurchase intention. Considering that regret reflects cognitive dissonance hence it can be said that the regret may influence repurchasing intention through attitude (Lerbin, 2015). In this way, attitude has a mediating variable on the effect of regret on repurchase intention.

\section{METHODOLOGY}

\section{DATA COLLECTION METHOD AND MEASURES}

The collection method of data was a face to face survey, administered in Turkish. Judgment sampling method was applied. This method is also known as purposive sampling, selective, or subjective sampling. It is a form of non-probability sampling in which researchers rely on their own judgment when choosing members of the population to participate in their study. This sampling method requires researchers to have prior knowledge about the purpose of their studies so that they can properly choose and approach eligible participants (Tongco, 2007: 147; Black, 2010: 225).

The survey consisted of forty-nine items in total firstly: regret (3-items), attitude (5-items), repurchase intention (5-items), and guilt (36-items). Since the reliability of the social responsibility guilt is very low and the number of statements remains in one statement, it could not be included in the study. Finally, four items were eliminated and forty-five items were used. All items were adapted to Turkish language. In this paper, regret scale developed by Bui et al. (2011), attitude and repurchase 
intention scale developed by Lerbin (2015), and guilt scale developed by Burnett (1988) are used. The scale to assess the feeling of guilt was expanded using various statements (marked with "*" in Appendix).

The questionnaire was firstly applied to Turkish consumers in Turkey and then the scales were translated into English with the support of a professional translator. The items were prepared on five-point Likert scale ( $1=$ Strongly Agree, $5=$ Strongly Disagree) (Mackinnon and Wang, 2020). Based on the good pretest results, the main study has been conducted. SPSS 20.0 and LISREL 8 were used to test hypotheses.

\section{PARTICIPANTS AND PROCEDURE}

Judgment sampling method was used. The sample size was found to be $\mathrm{n}=384$ at $95 \%$ confidence interval with a margin of error of $5 \%(e=5 \%)$. The calculated sample size was 450 smokers. Bryman and Cramer (2001) suggest that the number of participants should be five or ten times of the number of items in the scale in factor analysis. Therefore, there were 450 participants in the study group as ten time of the number of items. However, after the eliminated questionnaires, 429 data were obtained. Considering study groups, it can be stated that the number of participants $(n=429)$ was enough for validity and reliability analysis as five or ten times of the number of items.

The data was treated and cleaned before undertaking statistical analysis and the data checked for missing data. After data collection, data is entered into the SPSS program. Then, the data cleaning process is started to increase the data quality and to ensure the validity, accuracy and consistency of the analysis. In data cleaning, incorrect and missing data are identified in the data set, incorrect data are removed from the data set, and missing data are replaced by means of the variable using the SPSS program. After the elimination of incomplete or incorrect forms, 429 questionnaires were subject to analysis. Also, there were checks on normality of the data given that only a sample of 429 out of Izmir population participated. Skewness and Kurtosis values were examined for normality test. The Skewness value was found to be between -1.03 and 1.11 , and the Kurtosis value ranged from 1.38 to -.012 . When Kurtosis and Skewness values are between -1.5 and +1.5 , it is accepted that there is normal distribution (Tabachnick and Fidell, 2013).

\section{FACTOR ANALYSIS AND RELIABILITY}

A pre-test was applied to test the validity and clarity of the questionnaire before final analyses. A total of 20 consumers involved in this pre-test. According to the pre-test, social responsibility guilt was excluded from the final version. There are two reasons of this elimination. The first one is that the reliability of the social responsibility scale was very low (smaller than 0.60 ). The second reason is that the scale remained just with one variable by low factor loadings. Also in the preliminary test, it was determined that the mean values and the reliability of this dimension were very low. Despite the fact that expressions are revised, the reliability of this scale was again low as a finding of this study.

After pre-test, the study uses Exploratory Factor Analysis (EFA) in determining the validity of the instrument. EFA was conducted to identify and organize a large number of items of the questionnaire into the constructs under one specific variable (Chua, 2014). As suggested EFA was to be conducted to determine a structure of latent dimensions among the observed variables reflected in the items of an instrument (Hair et al., 2010). Therefore, this study was undertaken to produce empirical evidence of the validity and reliability.

Exploratory factor analysis (EFA) was applied all constructs (guilt, regret, attitude, repurchase intention) to determine the number of common factors. EFA is used to construct the research model and generally is applied before Confirmatory factor analysis (CFA) is done. Following the EFA, CFA was conducted to test the validity of the scales for the sample (Brown, 2015). The result of this analysis showed in the Table 1.

After the factor analysis was performed to assess repurchase intentions, the item "REP5" (I do not buy any other thing to substitute when I cannot find any tobacco) was excluded due to its factor loading of less than 0.50 , and the analysis was repeated. It was decided not to have this factor because it was unable to explain the structure and was removed from the new model obtained from the analysis (i.e., Figure 2). 
Table 1: The Results of Factor Analysis

\begin{tabular}{|c|c|c|c|c|}
\hline Items & $\begin{array}{l}\text { Factor } \\
\text { Loads }\end{array}$ & $\begin{array}{l}\text { Eigen } \\
\text { value }\end{array}$ & $\begin{array}{l}\text { Percentage } \\
\text { Variance }\end{array}$ & $\begin{array}{l}\text { Cumulative } \\
\text { Variance }\end{array}$ \\
\hline Financial Guilt=FINANCE & & 5.264 & 26.318 & 26.318 \\
\hline $\begin{array}{l}\text { FIN3 I do not feel bad when I buy tobaccotobacco, although the others see buying tobacco } \\
\text { /smoking as a waste. }\end{array}$ & .781 & & & \\
\hline FIN4 | feel guilty when I spend money on smoking instead of buying my needs. & .663 & & & \\
\hline FIN5 Although I do not approve buying tobacco /smoking, I do not feel regret when I buy ${ }^{\oplus}$ & .773 & & & \\
\hline $\begin{array}{l}\text { FIN10 Although I know that it affects the household budget adversely, I do not regret } \\
\text { buying tobacco. }\end{array}$ & .776 & & & \\
\hline FIN11 I do not feel regret, even if buying tobacco turns into an unplanned purchase ${ }^{\circledR}$ & .664 & & & \\
\hline Health Guilt=HEALT & & 3.190 & 15.948 & 42.266 \\
\hline HEA1 As I know smoking is harmful for my health, I feel regret when I smoke/buy tobacco. & .811 & & & \\
\hline $\begin{array}{l}\text { HEA2 Since smoking restricts my body movements (inability to climb up stairs, inability } \\
\text { to run etc.), I feel regret when I smoke/buy tobacco. }\end{array}$ & .755 & & & \\
\hline $\begin{array}{l}\text { HEA3 Since tobacco contain many harmful substances, I feel regret when I smoke/buy } \\
\text { tobacco. }\end{array}$ & .829 & & & \\
\hline $\begin{array}{l}\text { HEA5 I feel more regret than non-smokers when I do not undergo my annual routine } \\
\text { health checks. }\end{array}$ & .658 & & & \\
\hline HEA6 I feel concerned over my health when I smoke too much. & .728 & & & \\
\hline HEA7 I feel concerned over my health every time I smoke/buy tobacco. & .757 & & & \\
\hline $\begin{array}{l}\text { MOR7 I feel guilty when I think that I am harming my family, friends and other people } \\
\text { around me. }\end{array}$ & .632 & & & \\
\hline MOR8 I feel guilty when I think that I am harming myself while smoking. & .764 & & & \\
\hline MOR9 I feel guilty when I think that my hair, clothes and breath smell bad after smoking. & .672 & & & \\
\hline Moral Guilt= MORAL & & 2.983 & 14.913 & 57.179 \\
\hline MOR1 If I think smoking is against my beliefs, I do not smoke/buy tobacco. & .837 & & & \\
\hline MOR2 I do not smoke/buy tobacco when I think smoking is morally wrong. & .882 & & & \\
\hline MOR4 | feel regret over smoking when I think that smoking is condemned by the society. & .785 & & & \\
\hline $\begin{array}{l}\text { MOR5 Even if smoking is against my moral values, it does not influence my decisions on } \\
\text { smoking/buying tobacco }\end{array}$ & .551 & & & \\
\hline MOR6 I do not smoke/buy tobacco when I think smoking is not right. & .607 & & & \\
\hline MOR10 The legal regulations imposed to ban smoking in certain areas make me feel guilty. & .508 & & & \\
\hline \multicolumn{5}{|l|}{ KMO=0.880; Bartlett Test of Sphericity $=4141.202 ;$ df: $190 ; p<0.000 ;$ Cronbach's alpha $=0.80$} \\
\hline Consumer Regret=REGRET & $\begin{array}{l}\text { Factor } \\
\text { Loads }\end{array}$ & $\begin{array}{l}\text { Eigen } \\
\text { value }\end{array}$ & $\begin{array}{l}\text { Percentage } \\
\text { Variance }\end{array}$ & $\begin{array}{l}\text { Cumulative } \\
\text { Variance }\end{array}$ \\
\hline REG1 I feel bad when I smoke/buy tobacco. & 0.907 & 2.299 & 76.630 & 76.630 \\
\hline REG2 I feel regret after I smoke/buy tobacco. & 0.896 & & & \\
\hline $\begin{array}{l}\text { REG3 Sometimes I think it would be better in every aspect to buy another thing instead } \\
\text { of tobacco. }\end{array}$ & 0.821 & & & \\
\hline \multicolumn{5}{|l|}{ KMO=0.699; Bartlett Test of Sphericity $=585.087 ; \mathrm{df}: 3 ; \mathrm{p}<0.000 ;$ Cronbach's alpha $=0.85$} \\
\hline Attitude $=$ ATTITUDE & $\begin{array}{l}\text { Factor } \\
\text { Loads }\end{array}$ & $\begin{array}{l}\text { Eigen } \\
\text { value }\end{array}$ & $\begin{array}{c}\text { Percentage } \\
\text { Variance }\end{array}$ & $\begin{array}{c}\text { Cumulative } \\
\text { Variance }\end{array}$ \\
\hline ATT1 Despite its negative effects, smoking gives me pleasure. & 0.915 & 3.910 & 78.198 & 78.198 \\
\hline ATT2 Despite everything, smoking still makes me psychologically relieved. & 0.888 & & & \\
\hline ATT3 I like smoking despite its harmful effects. & 0.876 & & & \\
\hline ATT4 Despite everything, I feel like I am having a good time when I smoke. & 0.872 & & & \\
\hline ATT5 Smoking makes me happy. & 0.869 & & & \\
\hline \multicolumn{5}{|l|}{ KMO $=0.874 ;$ Bartlett Test of Sphericity $=1726.901 ; \mathrm{df}: 10 ; \mathrm{p}<0.000 ;$ Cronbach's alpha $=0.93$} \\
\hline Repurchase Intention=REPURCHA & $\begin{array}{l}\text { Factor } \\
\text { Loads }\end{array}$ & $\begin{array}{l}\text { Eigen } \\
\text { value }\end{array}$ & $\begin{array}{l}\text { Percentage } \\
\text { Variance }\end{array}$ & $\begin{array}{l}\text { Cumulative } \\
\text { Variance }\end{array}$ \\
\hline REP1 Despite its negative effects, I still buy tobacco when I need to. & 0.878 & 2.538 & 63.458 & 63.458 \\
\hline REP2 Despite everything, I still give priority to buying tobacco over other goods. & 0.804 & & & \\
\hline REP3 Despite everything, I will continue buying tobacco as I know I will be happy. & 0.764 & & & \\
\hline REP4 Despite everything, I still intend to continue smoking/buying tobacco. & 0.733 & & & \\
\hline $\mathrm{KMO}=0.690 ;$ Bartlett Test of Sphericity $=685.270 ; \mathrm{df}: 6 ; \mathrm{p}<0.000 ;$ Cronbach's alpha $=0$ & .81 & & & \\
\hline
\end{tabular}




\section{ASSESSMENT OF THE MEASUREMENT MODEL}

The measurement model was constructed according to the goodness of fit used in the evaluation of the structural model by using LISREL 8.80 . In this context, several modifications were made by the deletion of items with lower factor loadings to ensure goodness of fit. Hypotheses were tested by Maximum Likelihood Method. CFA was performed to test the validity of the scales. When the goodness of fit values of the variables was examined, some variables were found to be unacceptable. [(AGFI: health guilt: 0.78; purchase intention: 0.58); (NNFI: repurchase Intention: 0.76) and (RMSEA: financial guilt: 0.081; health guilt: 0.152 ; moral guilt: 0.092 ; attitudes: 0.179; purchase intention: 0.299)]. Then, necessary modifications were made with that scales were reached at an acceptable level of reliability after the exclusion of some items (FIN11, MOR10, HEA7, MOR7, MOR8, MOR9, ATT3, ATT5, and REP4).

At the end of the measurement model, the goodness of fit values for the scales was as follows: RMSEA $=0.066$; $\mathrm{AGFI}=0.86 ; \mathrm{CFI}=0.92 ; \mathrm{GFI}=0.89 ; \mathrm{X} 2=621.63 ; \mathrm{X} 2 / \mathrm{df}=2.9$. Moore et al. (2013) stated that $R$ squared value $<0.3$ is accepted to be none or very poor; $R$-squared value $0.3<$ $r<0.5$ is accepted a weak or low effect; $R$-squared value $0.5<r<0.7$ is accepted a moderate effect; R-squared value $r>0.7$ is accepted strong effect. Financial guilt, $R^{2}$ values are in the range of $0.43-0.61$ and the $t$-values are in the range of $13.94-17.41(p<0.05)$. Moral guilt, $R^{2}$ values are in the range of $0.24-0.89$ and the $t$-values are in the range of $10.35-24.62(p<0.05)$. Health guilt, $R^{2}$ values are in the range of $0.35-0.82$, and the $t$-values are in the range of $13.05-23.57(p<0.05)$. Regret, $R^{2}$ values are in the range of 0.49-0.77 and the $t$-values are in the range of $15.79-21.90(p<0.05)$. Attitudes, $R^{2}$ values are in the range of $0.66-0.80$, and the $t$-values are in the range of 19.67-22.82 $(p<0.05)$. Repurchase intention, $R^{2}$ values are in the range of $0.47-0.59$, and the $t$-values are in the range of $14.55-16.80(p<0.05)$. The result of this analysis showed in the Table 2.

\section{STRUCTURAL MODEL EVALUATION AND HYPOTHESIS TESTS}

Structural Equation Modeling (SEM) was used to test the hypotheses in Figure 2. In that sense, construct reability (CR), convergent validity (CV) and divergent validity (DV) was assessed. In addition, $C R$ should take a greater value than the Average Variance Extracted (AVE). DV should point out the difference between two separate structures (Matthes and Ball, 2019). With the purpose of attaining an acceptable DV value, the correlation between the structures must be lower than the square roots of AVE (Hair et al., 2006: 777). In addition, when determining $D V$ maximum shared variance values should be lower than AVE (Forrell and Lacker, 1981).

In Table 3, the values on the diagonal line are higher than the values on its row and line. This supports the distinctiveness, and shows that all construct are distinct in nature.

Table 2: The Results of Measurement Model

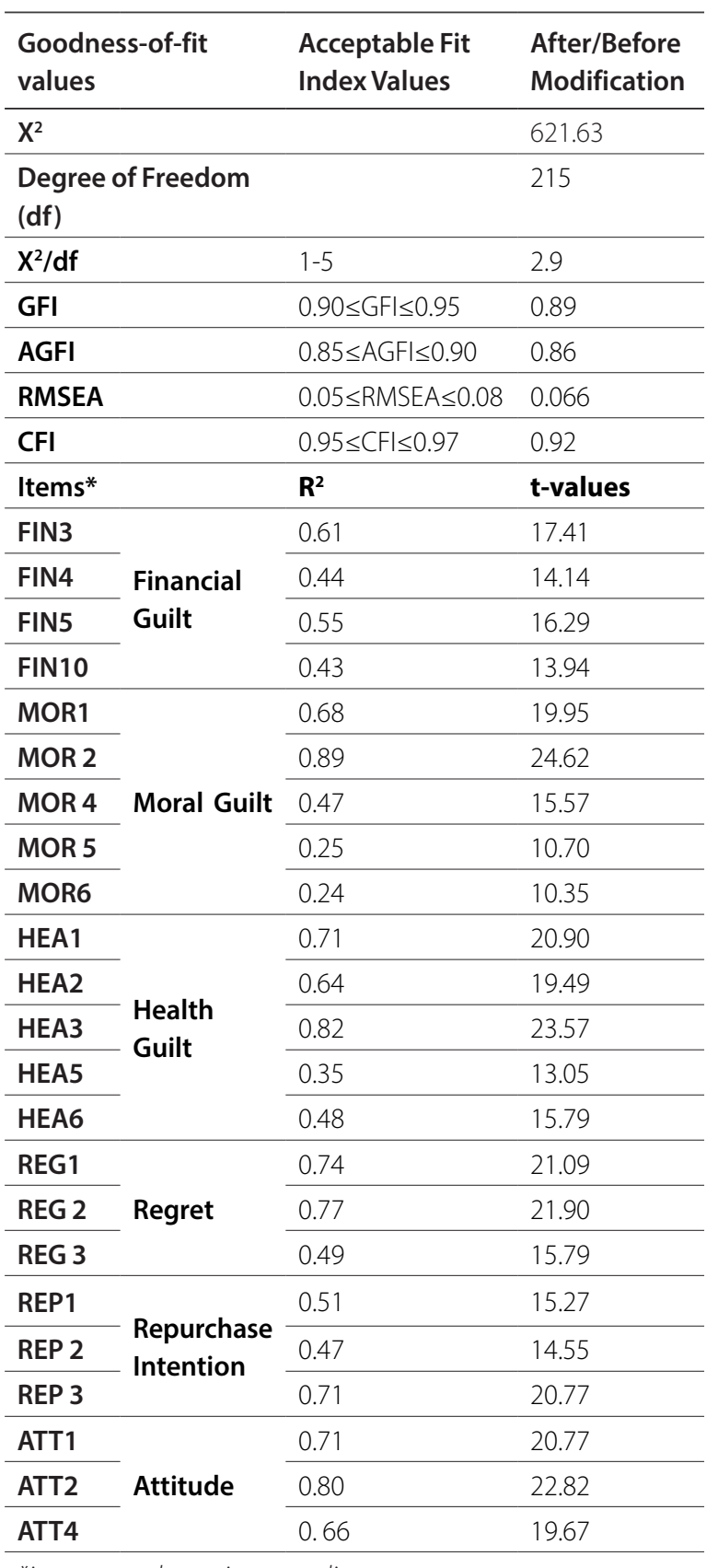

*items were shown in appendix 
Table 3: Divergent Validity

\begin{tabular}{|c|c|c|c|c|c|c|c|c|c|}
\hline & 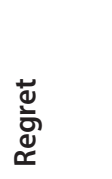 & 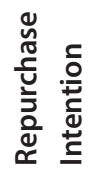 & 竞 & 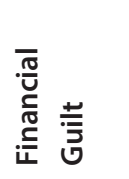 & 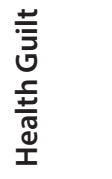 & $\begin{array}{l}\frac{ \pm}{3} \\
\frac{0}{\pi} \\
\frac{0}{2} \\
\sum\end{array}$ & 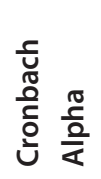 & 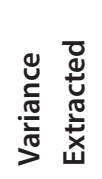 & 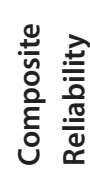 \\
\hline Regret & $(0.81)$ & & & & & & 0.85 & 0.66 & 0.85 \\
\hline Repurchaselntention & 0.24 & $(0.72)$ & & & & & 0.76 & 0.52 & 0.77 \\
\hline Attitude & 0.21 & 0.71 & $(0.85)$ & & & & 0.88 & 0.72 & 0.88 \\
\hline Financial Guilt & 0.58 & 0.14 & 0.12 & $(0.71)$ & & & 0.81 & 0.50 & 0.80 \\
\hline Health Guilt & 0.67 & 0.16 & 0.14 & 0.42 & $(0.77)$ & & 0.87 & 0.60 & 0.88 \\
\hline Moral Guilt & 0.24 & 0.06 & 0.05 & 0.20 & 0.03 & $(0.71)$ & 0.81 & 0.52 & 0.83 \\
\hline
\end{tabular}

Table 4: Estimated Values for Structural Equation Model

\begin{tabular}{lcccc}
\hline & $\begin{array}{c}\text { Standardized } \\
\text { coefficient }\end{array}$ & $\mathbf{R}^{2}$ & Error Variance & $\mathbf{t}$-value \\
\hline Financial Guilt $\rightarrow$ Regret & 0.32 & 0.59 & 0.41 & 6.39 \\
\hline Health Guilt $\rightarrow$ Regret & 0.54 & 0.59 & 0.41 & 10.65 \\
\hline Moral Guilt $\rightarrow$ Regret & 0.18 & 0.59 & 0.41 & 4.46 \\
\hline Regret $\rightarrow$ Attitude & -0.21 & 0.04 & 0.96 & -3.88 \\
\hline Regret $\rightarrow$ Repurchase Intention & -0.09 & 0.56 & 0.44 & -1.81 \\
\hline Attitude $\rightarrow$ Repurchase Intention & 0.72 & 0.56 & 0.44 & 12.19 \\
\hline
\end{tabular}

As shown in Table 4 and Figure 2, all types of guilt had a significant and positive effect on the feeling of regret, and attitudes had a significant and positive effect on repurchase intention. Moreover, feeling of regret had a negative effect on attitudes. The effect of regret on repurchase intention was not found as significant. The results of hypotheses were shown in Table 5.

Table 5: The Results of Hypotheses

\begin{tabular}{lc}
\hline Hypotheses & Results \\
\hline H1a: Consumers' financial guilt has a positive effect on regret. & Supported \\
\hline H1b: Consumers' health guilt has a positive effect on regret. & Supported \\
\hline H1c: Consumers' moral guilt has a positive effect on regret. & Supported \\
\hline H2a: Consumer regret has a negative effect on attitude. & Supported \\
\hline H2b: Consumer regret has a negative effect on repurchase intention. & Not Supported \\
\hline H3: Attitudes towards smoking has a positive effect on repurchase intention. & Supported \\
\hline H4: Attitudes towards smoking has a mediating role on the effect of regret on repurchase intention. & Supported
\end{tabular}




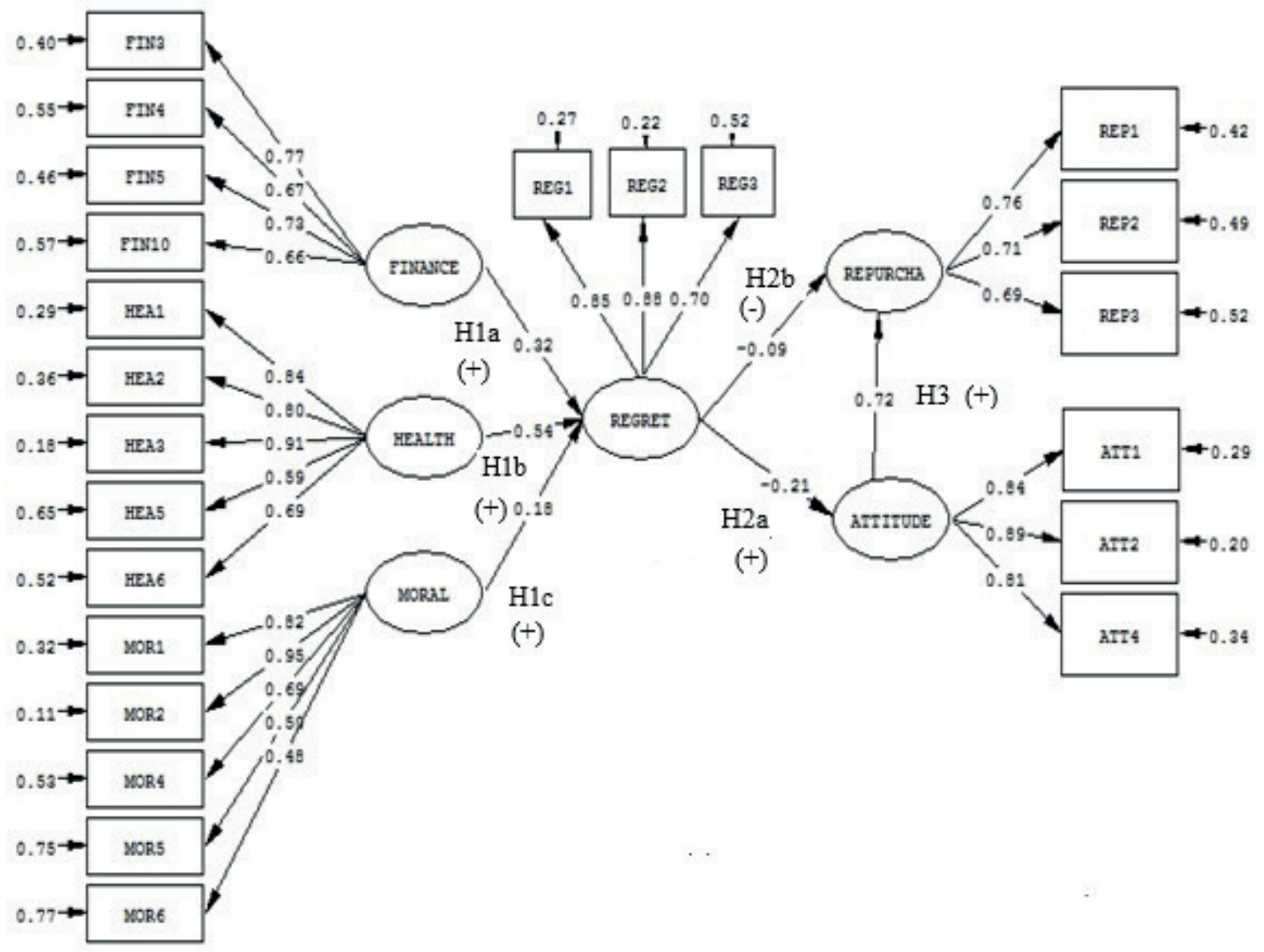

Figure 2: Structural equation model

According to the structural model model fit index are as below:

$X^{2}$ : 688.17; df: 221; P-value: 0.0001; AGFI: 0.85; GFI: 0.88; RMSEA: 0.070; CFI: 0.91; NNFI: 0.89; NFI: 0.87 .

Fit index values of measurement model and structural model are generally in range of acceptable fit index values. But some of them are not in this range. According to some researchers, fit indices values within the range between 0.80 and 0.89 are also acceptable (Segars and Grover, 1993; Doll et al., 1994; Hu and Bentler, 1998; Schermelleh-Engel et al., 2003; Hooper et al., 2008).

\section{MEDIATION TEST}

It is necessary to define whether the direct effects of independent variable on dependent variable are significant or otherwise. Hence, in order to define the mediator effect, a macro (PROCESS) for SPSS developed by Hayes (2015) was used. This macro also generates bootstrap confidence intervals for an indirect effect (Reutter and Bigatti, 2014). Thus Sobel Test was used to test the significance of a mediation effect. In the Sobel
Test, z-score greater than 1.96 indicates the existence of mediating effect. To determine how effective, the mediating variable is on the relationship, it is important to determine the total, direct and indirect effects and the bootstrap confidence intervals should be used to decide whether the indirect effect is significant (Pham et al., 2019).

Figure 3 shows that three criteria for mediating effect have been met, and that these paths are found as significant. An examination of path c shows that the mediating effect is not significant. This finding is important, but not sufficient evidence of the existence of a mediating effect. Partial mediation refers to a pattern of findings where mediation is established in the presence of significant total effect of $X$ and the direct effect of $X$ ( $c^{\prime}$ ) is statistically different from zero (Hayes and Rockwood, 2017: 40). Since the $z$-score $(Z=3.166 ; P=0.000)$ obtained in the Sobel Test is significant and larger than 1.96, a partial mediating effect can be said to exist.

Table 6 shows the bootstrap confidence intervals which determine the size and significance of mediating 
effect. In bootstrapping, both the lower and upper bounds should be below or above 0 (Preacher and Hayes, 2008). As shown in Table 6, as both values are below 0 in this study, attitudes can be considered to have a partial mediating effect on the relationship between the feelings of regret and repurchase intention. Thus, $\mathrm{H} 4$ was supported.

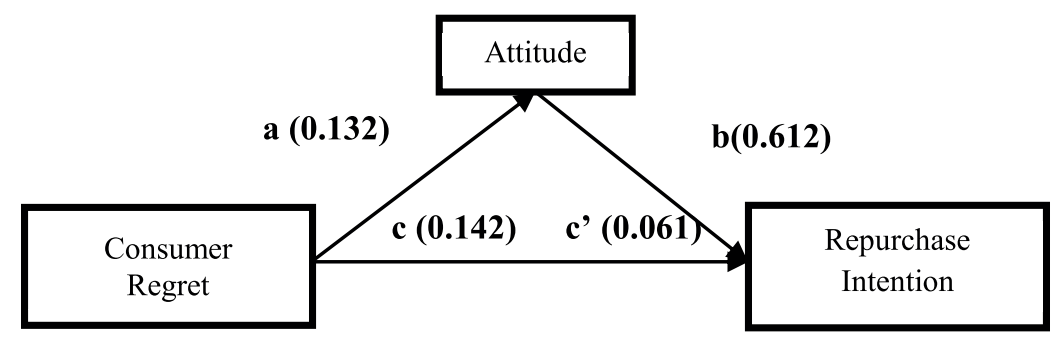

Sobel Z-score $=3.166 \mathrm{p}=0.00$

Figure 3: Mediating role of attitude

Table 6: Total, Direct and Indirect Impact Values

\begin{tabular}{llllll}
\hline $\begin{array}{l}\text { The Effect of the Attitude on } \\
\text { Relationship }\end{array}$ & $\begin{array}{l}\text { Total } \\
\text { Effect }\end{array}$ & $\begin{array}{l}\text { Direct } \\
\text { Effect }\end{array}$ & $\begin{array}{l}\text { Indirect } \\
\text { Effect }\end{array}$ & $\begin{array}{l}\text { Bootstrap Confidence } \\
\text { Interval } \\
\text { BoLLCI-BoULCl }\end{array}$ & $\begin{array}{l}\text { Type of } \\
\text { Mediation }\end{array}$ \\
\hline Regret $\rightarrow$ Repurchase Intention & 0.142 & 0.061 & 0.081 & $(-0.1370)-(-0.0275)$ & Partial \\
\hline
\end{tabular}

\section{DISCUSSION AND CONCLUSION}

Despite the recent legal regulations aimed at reducing smoking rates, the intention to smoke is still increasing among young adults especially in developing countries such as Turkey (Uzundumlu and Topcu, 2015; Cetin, 2017). Given the early age of smoking initiation, researching the habit of smoking has become a priority. Although consumers know the harm of smoking and show negative attitudes, they continue to smoke. As Johnson et al. (2010) stated many smokers who show dissonance of the attitudes towards the brand and the industry. Although smokers know their harm, they continue to smoke.

This research contributes to examine the relationship between guilt and regret arising from tobacco consumption. Zhang et al. (2020) emphasized that according to the theory of self-discrepancy, guilt and regret were different emotional experiences, although there was a high correlation between them. Guilt is associated with a more moral self-blame than regret and is caused by interpersonal harm (Lickel et al., 2014). Regret is caused by both self-harm (Berndsen et al., 2004) and harm to others (Zeelenberg and Breugelmans, 2008). The results of this study indicated that guilt affects regret positively; regret occurs as a consequence of guilt, parallel to the literature (Landman, 1993; Dijkstra et al., 2008; e Silva and Martins, 2017). Williamson et al. (2020) stated that the psychological experiences of guilt and regret are closely related to smoking experience. As Vosgerau et al. (2016) investigated guilt and regret for hedonic consumption, this study indicated that consumer felt guilt and then regret in addictive products such as smoking.

This study investigated the effects of each guilt type on regret. The findings of this study were that health and financial guilt were more effective than moral guilt to trigger smoking-related feeling of regret. This result is consistent with other previous study (Sansone et al., 2013).

This paper aims to investigate effects of regret on tobacco repurchase intention by assessing the mediating role of attitude towards tobacco. Unlike other studies, which detected that negative relationship exists between regret, as expression of cognitive dissonance, and repurchase intention, this study found that regret have no effect on repurchase intention (Conner et al., 2006; Keng and Liao, 2009; Lerbin, 2015). Consistent with previous research, negative emotions (regret, guilt etc.) reduce the intention of repurchase behavior. Fong et al. 
(2004) mentioned that a smoker who has experienced regret has positive intentions to quit smoking. According to Koch (2014), it is predicted that anticipated regret for smoking affects low intentions to start or continue smoking. However, Fazal-e-Hasan et al. (2020) emphasized that regret was not found sufficient for smokers' intention to quit smoking or to repurchase. In order for smokers not to buy again or be willing to quit, they must have self-control and have information about ways to quit smoking, and a support must be provided from the environment. Sansone et al. (2013) stated that in countries where tobacco control is low and weak, this situation affects the social norms of smoking less, and therefore regret for smoking is felt less. Strong tobacco policies have been found to be effective in the formation of regret due to smoking. These tobacco policies may affect the health damage caused by smoking, negative social norms and the financial cost of purchasing cigarettes.

By comparing the harms of smoking with the benefits such as pleasure, enjoyment, relaxation and happiness, smokers perceive the benefits of smoking more than the perceived harms (Oakes et al., 2004). This stituation can increase the rationalization of smoking behavior and cause less regret due to smoking. Therefore, rationalization of smoking does not affect the intention to quit, repurchase due to the feeling of less regret. For this reason, Lee (2007) mentioned that social norms and culture may be effective to quit intention or to repurchase. Due to factors not included in the study, such as inadequate tobacco control policies, rationalization, social norms, and cultural influence, there may be no relationship between regret and repurchase intention towards smoking.

It can be determined that regret because of smoking has a negative effect on attitudes. The findings of this paper are parallel to the findings of previously held studies (Keng and Liao, 2009; Lerbin, 2015). The cognitive dissonance theory provides a framework for understanding inconsistencies among consumers who understand the dark side of consumption (Gregor$y$-Smith et al., 2013), but still continue to smoke. The findings indicated that attitudes towards smoking were found to have a positive effect on repurchase intention and is in line with previously held studies (Lerbin, 2015). The researchers found that more positive attitudes of consumers towards tobacco smoking in the past, the greater the intent to repurchase tobacco in the future, and vice versa. It was also found that attitudes had a mediating role in the effect of regret on repurchase intentions, paralel with some studies (Keng and Liao, 2009).

\section{THEORITICAL CONTRIBUTION}

The study has theoretical contributions. This study emphasizes that guilt and regret have not been a major focus in the marketing literature, and they need to be better investigated to reveal their effects on consumer behavior. In the literature, tobacco consumption has been studied separately with guilt (Fong et al., 2004; Lee and Paek, 2014) and regret (Lazuras et al., 2012; Nayak et al., 2017). Furthermore, a limited number of studies in medicine or psychology have been found where these two are studied together. Therefore, the first contribution of this study was that the investigation on guilt and regret which has been showed together to examine the relationship between guilt and regret arising out of tobacco consumption. Financial, health, moral and social responsibility guilt would diminish consumer's positive response and may cause regret (Shiffman and Paty, 2006). Hence, the second contribution of this study is that the effects of each guilt type on regret have been investigated. This study is also related to the tobacco consumption with the feelings of guilt and regret, and examining effect of regret on repurchase intention and attitude. Accordingly, the last contribution is to better understand the effects of regret on tobacco repurchase intention by assessing the mediating role of attitude. If the relationship between independent variable and dependent variable decreases, partial mediation effect can be mentioned (Howell, 2013: 547). In this study, an attitude is a partial mediating effect between the feelings of regret and repurchases intention.

\section{MANAGERIAL IMPLICATIONS}

The results of this study may contribute to practicioner understanding of tobacco consumption as cognitive-based and a cause of incompatibility in consumers' behavior. In order to affect and change attitudes towards smoking, cognitive factors should be considered by businesses in all activities and strategies. This research provides support for the development of social marketing campaigns. In order to increase feelings of regret among consumers, advertisement policies should focus not only on health but also on financial and moral guilt. In this way, smoking can be demonstrated as something which has to be regretted, sharing corrective messages that help them to quit smoking (Lee et al., 2019). Razaet al. (2018) determined that the message used in anti-smoking advertisements should be persuasive and based on knowledge and humor rather than fear, in order to 
encourage the consumer to quit smoking. In this context, it is emphasized that messages should be designed to explain what it does to health and why you should quit the habit. In addition, it has been found that emotional messages are more effective than other message strategies with the use of graphic images to encourage smoking cessation behavior (Davis et al., 2017). Yoo and Eastin (2017) emphasized that social media, video games, wearable devices and mobile technologies create mutually interactive environments, and increase awareness by providing educational entertainment oriented health messages for non-smoking campaigns. Yang (2018) stated that messages such as reward and benefit instead of fear based messages for the positive effects of smoking cessation were more effective in quitting smoking. Media campaigns using negative advertising are regarded as effective public health tools that lead to behavioral change. It is not sufficient, therefore, to address the harms of smoking only on the packages themselves. Rather ad agencies must also make more efficient use of negative advertising (Wymer, 2015, 2017). Visual and written warnings on tobacco packages are the most frequent deterrent methods in countries where tobacco advertising is prohibited.

Social media can be used as an effective media tool to present harmful effects of smoking. Social media platforms support efforts to quit smoking interactively, allowing users to share text, audio, photos, images, or videos to interact and support their own experiences. In this way, social media provides a platform for participants to learn about their smoking cessation performance and difficulties, improve their personal skills and social modeling from other participants. In addition, social media enables participants to provide a change in their health behavior, increase self-efficacy or trust on themselves through peer motivation, encouragement and, learning about quitting smoking. Social media facilitates this through personalized incentives and social persuasion (Naslund et al., 2017). Thus, people send interfering content created especially through special groups created on social media. In this way, social media enables users to interact with content posted on their profiles (eg Smokefree.gov's Facebook page) (Thrul et al. 2019). Namkoong et al. (2017) emphasized that the increase in social media use will change the attitudes and perceived social norms of consumers regarding smoking behavior and play an important role in reducing the intention to smoke accordingly. Social networks such as Facebook and Twitter (SNSs) can be used as a campaign tool aimed at interactive health communication, especially for young adults. It has been demonstrated that interactive social media campaigns will be more effective in quitting smoking as they will create collective efforts with community-based participatory projects (Brabham et al., 2014). Yoo et al. (2016) stated that social media is an interactive communication channel especially for university students to quit smoking, to produce content, share and interpret in an interactive way. Through the anti-smoking messages developed in the social media environment, more people will be exposed to these messages to improve or change individuals' attitudes and behavioral intentions. Antismoking messages highlighting the negative health consequences of smoking are found to be the most persuasive tool to change the knowledge, negative attitudes and beliefs of university students about tobacco use (Terry-McElrath et al., 2013). In this regard, it was emphasized that public health practitioners can use social media as an active intervention platform for university students to prevent and quit smoking.

When the Turkish literature is analyzed, it is determined that there are not many studies investigating the role of social media in smoking cessation. Erkek (2016) stated that beneficial results can be obtained since the Ministry of Health makes informative posts by using social media in smoking cessation campaigns. Ince and Koçak (2017) examined the smoking habits of the staff working in public institutions. This study determined that the employees use the internet mostly in obtaining information about the harm of tobacco products, followed by television and social media, respectively. In addition, it was found that there was an increase in the level of trust in social media due to the increase in the level of importance given by the employees to the internet among other media types in obtaining information about the harms of smoking.

In terms of behavioral factors, information and incentives about smoking-related deaths, or negative effects of smoking on health may create a perception that smokers are vulnerable to such effects. Companies can play a more active role in reducing smoking rates among employees by increasing the number and frequency of information telephone services, workplace clinics and free medical support services. Furthermore, companies should provide training on health to increase awareness, and should offer instructive anti-smoking programs, as well as supervising the supply of tobacco and tobacco products and expanding the scope of such supervision.

This study has some implications for public policy makers as well. There is a need to increase the number of trainings and social awareness activities which may prove as important actions to reduce smoking intentions. The 
effect of consumers' regret on attitude about tobacco can only be reduced by education and awareness programs. Public education is essential to reduce smoking rate through restricting the age at which people could purchase tobacco, marketing on television and increasing prices via taxation (Wymer, 2015). The studies investigated the impact of increasing taxes and prices on the consumption of tobacco products in Turkey; some studies have indicated the reduced tobacco products consumption as a result of these actions (Karaöz et al., 2010; Buyrukoğlu et al., 2016); in some studies, as a result of the measures taken, it was determined that consumers have shifted to cheap, substitute and illegal product consumption (Uğur ve Kömürcüler, 2015; Durmusoğlu, 2017; Cetin and Özkan, 2018; Beser and Askan, 2019). In this respect, it was emphasized that taxes and price increases on tobacco products cannot be effective alone in reducing tobacco products consumption (Hayrullahoglu, 2015).

Hence, in order to increase effectiveness of anti-smoking policies, actions must be taken to increase conscious of the harm caused, with a particular emphasis on the harm of smoking to the environment and to others. For instance, ads showing the effects of smoke and carelessly discarded tobacco can be used to promote a healtier world. Within the framework of legal regulations and laws imposed by the government to prevent or reduce smoking, continuity is important to impose restrictions and controls in potential segments. In order to reduce the harm from tobacco industry, it is not sufficient to apply only short term policies such as package design, increase taxes, but also long term progressive policies such as removing nicotine from tobacco and tobacco products (Wymer, 2017).The findings of this study implied that financial guilt was found to be the second most experienced type of guilt. This indicates that beside health guilt, government imposed financial measures would be beneficial by increasing tobacco taxes together with an increase in price. In particular, to help smokers overcome guilt and regret, a range of social support is needed. Especially, Carneiro et al. (2017) has found that social interactions with the family and the reference groups are effective in the change of attitudes of consumers, especially among young people. Therefore, environmental factors, i.e. family, workplace, and schools, as influential institutions, should act in harmony to change consumer's attitudes. These groups act in cooperation with media, educational bodies, governmental practices and legal regulations. In addition, society should be convinced that smoking is a social norm and an undesirable behavior via anti-smoking campaigns (Cohen and Anglin, 2009). The cognitive messages may be provided about the harm of smoking by all organizations. Studies have been conducted by the Ministry of Health and non-governmental organizations for the purpose of protecting children and young people from the harmful effects of tobacco products in Turkey with the participation of volunteered young people. In this context, "Youth Action Plan for Combating Tobacco" was prepared in 2016. Within the scope of this action plan, young people were given "Peer Education Program for My Fight against Tobacco" trainings. These preventive trainings are still continuing today, and the adverse effects of tobacco use on health and the harm of tobacco addiction are explained to the youth. In addition, tobacco products are not sold in schools and universities in order to protect children and young people from using tobacco products and to prevent their accessibility (Havanı Koru Saglik Bakanligi).

\section{LIMITATIONS AND FURTHER RESEARCH}

This paper has a few numbers of limitations. Initially, the sample of the study is only Izmir, thus the results cannot be generalized to other regions of Turkey. It focuses only on financial, moral and health guilt, and excludes social responsibility guilt. The other limitation of this research is that social desirability bias is present in face-to-face survey compared to the other research methods such as email, telephone, or self-administrated methods. Even though several aforementioned remedies had been taken in order to minimize this bias, the social desirability bias can be stated as the limitation of the study. In the future researches, the social desirability scale (Crowne and Marlowe, 1960) can be used, forced-choice items questions added and computerized self-administration can be hired which are more effective at reducing social desirability bias.

This study may have some other suggestions for future studies. Further studies may be conducted to examine strategies consumers use to overcome the feeling of regret after buying tobacco, and how this feeling affects their future purchases. The guilt type that leads to more regret after eating fast food or drinking alcohol may also be examined (Lemaster, 2010; Sandberg et al., 2016), and the range of products expanded. It would also be valuable to study the feelings of regret and guilt after purchases that are impulsive, unplanned, hedonic, and obsessive purchases. Since smoking rates may differ between developed and developing countries, comparative research can be conducted across geographies and cultures. Future studies may also involve analyzing the differences between light, heavy and social smokers. 


\section{References}

Arli, D., \& Leo, C. (2017). Why do good people do bad things? The effect of ethical ideology, guilt proneness, and self-control on consumer ethics. Asia Pacific Journal of Marketing and Logistics, 29(5), 1055-1078.

Bathaee, A. (2013). The double-edged sword of anticipated regret: Comparative study in Iran and Germany. Journal of International Consumer Marketing, 25(5), 344-359.

Baumeister, R. F., Stillwell, A. M., \& Heatherton, T. F. (1994). Guilt: an interpersonal approach. Psychological bulletin, 115(2), 243.

Baumeister, R. F. (2017). Addiction, cigarette smoking, and voluntary control of action: Do cigarette smokers lose their free will?. Addictive behaviors reports, 5, 67-84.

Bee, C. C., \& Madrigal, R. (2013). Consumer uncertainty: the influence of anticipatory emotions on ambivalence, attitudes, and intentions. Journal of Consumer Behaviour, 12(5), 370-381.

Ben-Ze'ev, A. (2000). The subtlety of emotions: MIT Press.

Berndsen, M., van der Pligt, J., Doosje, B., \& Manstead, A. (2004). Guilt and regret: The determining role of interpersonal and intrapersonal harm. Cognition and Emotion, 18, 55-70.

Beşer, B. H., \& Aşkan, H. Türkiye'de Sigara Bağımlıığını Azaltmada Sigara Vergilerinin Etkisi. Strategic Public Management Journal, 5(9), 65-78.

Bice, A. A. (2018). Cognitive Dissonance and Pediatric Procedural Pain Management: A Concept Clarification. Pain Management Nursing, 19(3), 230-237.

Black, K. (2010). Business Statistics: Contemporary Decision Making. 6th edition, John Wiley \& Sons.

Brabham, D. C., Ribisl, K. M., Kirchner, T. R., \& Bernhardt, J. M. (2014). Crowdsourcing applications for public health. American journal of preventive medicine, 46(2), 179-187.

Brewer, N. T., DeFrank, J. T., \& Gilkey, M. B. (2016). Anticipated regret and health behavior: A meta-analysis. Health Psychology, 35(11), 1264.

Bryman, A., \& Cramer, D. (2002). Quantitative data analysis with SPSS release 10 for Windows: A guide for social scientists. Routledge.

Brown,T. (2015) Confirmatory Factor Analysis for Applied Research, Second Edition, Guilford publications.

Buchanan, J., Summerville, A., Reb, J., \& Lehmann, J. (2016). The Regret Elements Scale: Distinguishing the affective and cognitive components of regret. Judgment and Decision Making, 11(3), May 2016, 275-286

Bui, M., Krishen, A. S., \& Bates, K. (2011). Modeling regret effects on consumer post-purchase decisions. European Journal of Marketing, 45(7/8), 1068-1090.

Burnett, M. S. (1988). Guilt as an individual difference variable: Scale development and predictive validity assessment. Doctoral dissertation, Oklahoma State University).
Burnett, M. S., \& Lunsford, D. A. (1994). Conceptualizing guilt in the consumer decision-making process. Journal of Consumer Marketing, 11(3), 33-43.

Burton, S., \& Nesbit, P. (2015). Capturing experiences as they happen: diary data collection for social marketing. Journal of Social Marketing, 5(4), 307-323.

Buyrukoğlu S., Bozdoğan D. \& Köktaş A. M. (2016). Paternalist Devlet Anlayışının Bir Gereği Olarak Günah Vergileri:Türkiye Örneği Niğde Üniversitesi Iktisadi ve Idari Bilimler Fakültesi Dergisi, 9(3),15-31.

Carneiro, J. S., Ramos, R. R., Carreiro, J. B. X., \& de Oliveira Brasil, M. V. (2017). Determinant Factors Leading to Tobacco Consumption: Implications for Social Marketing. REBRAE, 10(3), 381-399.

Chua, Y. P. (2014). Statistik Penyelidikan Lanjutan: Ujian Regresi, Analisis Faktor dan analisis Sem. Malaysia: McGraw Hill (Malaysia) Sdn Bhd.

Çetin, T. (2017). The effect of taxation and regulation on cigarette smoking: Fresh evidence from Turkey. Health Policy, 121(12), 1288-1295.

Çetin, M., \& Özkan, E. (2018). Türkiye'de Vergi-Tüketim İlişkisi: Alkol Ve Tütün Ürünlerine Yönelik Bir Saha Araştirmasi. Balıkesir Üniversitesi Sosyal Bilimler Enstitüsü Dergisi, 21(40), 271-288.

Cohen, J. E., \& Anglin, L. (2009). Outlet density: a new frontier for tobacco control. Addiction, 104(1), 2-3.

Conner, M., Sandberg, T., McMillan, B., \& Higgins, A. (2006). Role of anticipated regret, intentions and intention stability in adolescent smoking initiation. British Journal of Health Psychology, 11(1), 85-101.

Crowne, D. P., \& Marlowe, D. (1960). A new scale of social desirability independent of psychopathology. Journal of Consulting Psychology, 24(4), 349-354.

Dagli, E. (1999). Are low-income countries targets of the tobacco industry? International Journal of Tuberculosis and Lung Disease, 3, 113-118.

Davis, K. C., Duke, J., Shafer, P., Patel, D., Rodes, R., \& Beistle, D. (2017). Perceived effectiveness of antismoking ads and association with quit attempts among smokers: evidence from the tips from former smokers campaign. Health communication, 32(8), 931-938.

Dawkins, L., Acaster, S., \& Powell, J. H. (2007). The effects of smoking and abstinence on experience of happiness and sadness in response to positively valenced, negatively valenced, and neutral film clips. Addictive Behaviors, 32(2), 425-431.

Dedeoğlu, A. Ö., \& Kazançoğlu, İ. (2012). Consumer guilt: A model of its antecedents and consequences. EgeAkademik Bakıs Dergisi, 12(1), 9-22. 
Dijkstra, P., Kuyper, H., Van der Werf, G., Buunk, A. P., \& van der Zee, Y. G. (2008). Social comparison in the classroom: A review. Review of educational research, 78(4), 828-879.

Doll, W. J., Xia, W., \&Torkzadeh, G. (1994). A confirmatory factor analysis of the end-user computing satisfaction instrument. MIS quarterly, 453-461.

Durmuşoğlu (2017). Sigaradaki Fiyat Artışlarının Sigarayı Bırakma Kararına Etkisinin Internet Arama Trafiği Verileri ile Analizi, Gaziantep University, Journal Of Social Sciences, 16(2), 359-371.

e Silva, S. C., \& Martins, C. C. (2017). The relevance of cause-related marketing to post-purchase guilt alleviation. International Review on Public and Nonprofit Marketing, 14(4), 475-494.

Erkek, S. (2016). Kamu Kurumlarında Sosyal Medya Kullanımı: Sağlık Bakanlığı Örneği. Selçuk Üniversitesi Sosyal Bilimler Enstitüsü Dergisi, (35), 141-150.

Eurostat, (2015). https://ec.europa.eu/eurostat/statistics-explained/index.php?title=Tobacco_consumption_statistics

Fazal-e-Hasan, S. M., Ahmadi, H., Mortimer, G., Sekhon, H., Kharouf, H., \& Jebarajakirthy, C. (2020). The interplay of positive and negative emotions to quit unhealthy consumption behaviors: Insights for social marketers. Australasian Marketing Journal (AMJ). 1441-3582.

Festinger, L. (1957). An introduction to the theory of dissonance. A Theory of Cognitive Dissonance, 1-31.

Festinger, L., \& Carlsmith, J. M. (1959). Cognitive consequences of forced compliance. The Journal of Abnormal And Social Psychology, 58(2), 203.

Fishbein, M., \& Ajzen, I.(1975). Belief, Attitude, Intention, and Behaviour: An Introduction to Theory and Research: Addison-Wesley.

Fong, G. T., Hammond, D., Laux, F. L., Zanna, M. P., Cummings, K. M., Borland, R., \& Ross, H. (2004). The near-universal experience of regret among smokers in four countries: findings from the International Tobacco Control Policy Evaluation Survey. Nicotine \& Tobacco Research, 6 (Supplement 3), 341-351.

Fornell, C., \& Larcker, D. F. (1981). Evaluating Structural Equation Models with unobservable variables and measurement error. Journal of Marketing Research, 18(1), 39-50

Fotuhi O, Fong GT, Zanna MP, Borland R, Yong H, Cummings KM (2013). Patterns of cognitive dissonance-reducing beliefs among smokers: a longitudinal analysis from the International Tobacco Control (ITC) Four Country Survey. Tobacco Control 22(1): 52-58.

Ganatra, H. A., Kalia, S., Haque, A. S., \& Khan, J. A. (2007). Cigarette smoking among adolescent females in Pakistan. The International Journal of Tuberculosis and Lung Disease, 11(12), 1366-1371.

Greenwald, A. G., \& Ronis, D. L. (1978). Twenty years of cognitive dissonance: Case study of the evolution of a theory. Psychological Review, 85(1), 53.
Gregory-Smith, D., Smith, A., \& Winklhofer, H. (2013). Emotions and dissonance in 'ethical'consumption choices. Journal of Marketing Management, 29(11-12), 1201-1223.

Guo, Q., Johnson, C. A., Unger, J. B., Lee, L., Xie, B., Chou, C.-P., Pentz, M. (2007). Utility of the theory of reasoned action and theory of planned behavior for predicting Chinese adolescent smoking. Addictive behaviors, 32(5), 1066-1081.

Hair, J. F., Black, W. C., \& Babin, B. J. (2010). RE Anderson Multivariate data analysis: A global perspective. New Jersey, Pearson Prentice Hall).

Hair, F.J. Jr, Sarstedt, M., Hopkins, L. \& Kuppelwieser, G.V. (2014). Partial least squares structural equation modeling (PLSSEM) an emerging tool in business research. European Business Review, 26 (2), 106-121.

Havanı Koru Dumansız Hava Sahası, Türkiyede Tütünle Mücadele Süreci, https://havanikoru.saglik.gov.tr/surec.html

Hayes, A. F. (2015). An index and test of linear moderated mediation. Multivariate behavioral research, 50(1), 1-22.

Hayes, A. F., \& Rockwood, N. J. (2017). Regression-based statistical mediation and moderation analysis in clinical research: Observations, recommendations, and implementation. Behaviour research and therapy, 98, 39-57.

Hayrullahoğlu, B. (2015). Türkiye'de Tütün Mamulleri Ve Alkollü İçkilerde Özel Tüketim Vergisinin Başarısı. Journal of Life Economics, 2(2), 89-112.

Hyland, A., Li, Q., Bauer, J. E., Giovino, G. A., Steger, C., \& Cummings, K. M. (2004). Predictors of cessation in a cohort of current and former smokers followed over 13 years. Nicotine \& Tobacco Research, 6, Supplement 3, 363-369.

Hooper, D., Coughlan, J., \& Mullen, M. R. (2008). Structural equation modelling: Guidelines for determining model fit. Electronic journal of business research methods, 6(1), 53-60.

Howell, David C. (2013). Statistical Methods for Psychology, Wadsworth, Cengage Learning, 8.Edt., Belmont.

Hu, L. T., \& Bentler, P. M. (1998). Fit indices in covariance structure modeling: Sensitivity to underparameterized model misspecification. Psychological methods, 3(4), 424.

Johnson, S. E., Coleman, B. N., \& Schmitt, C. L. (2016). It's complicated: Examining smokers' relationships with their cigarette brands. Psychology of Addictive Behaviors, 30(8), 887.

Imhoff, R., Bilewicz, M., \& Erb, H. P. (2012). Collective regret versus collective guilt: Different emotional reactions to historical atrocities. European Journal of Social Psychology, 42(6), 729-742.

Inman, J. J., \& Zeelenberg, M. (2002). Regret in repeat purchase versus switching decisions: The attenuating role of decision justifiability. Journal of Consumer Research, 29(1), 116-128.

Ince, M., \& Koçak, M. C. (2017). Kamu Kurumlarında Çalışan Personelin Sigara Kullanma Alışkanlıkları. Electronic Turkish Studies, 12(13). 
Karaöz, M., Albeni, M., \& Büyüktatlı, F. (2010). Yasal Düzenlemelerin Sigara Tüketimi Üzerindeki Etkileri. Alanya Işletme Fakültesi Dergisi, 2(2), 19-36.

Katajavuori, N., Pietilä, K., Rajamäki, H., Järvinen, P., Teräsalmi, E., \&Hakuli, T. (2002). A Qualitative Study of the Difficulties of Smoking Cessation; Health Care Professionals'and Smokers' Pints of View. Pharmacy World and Science, 24(6), 240-246.

Kayli D.S, Yararbaş G. (2016). Ege Üniversitesi Meslek Yüksek Okulu Öğrencilerinin Sigara İçme Durumları, Celal Bayar Üniversitesi Sağlık Bilimleri Enstitüsü Dergisi, 2(5), 134-138

Keng, C.-J., \& Liao, T.-H. (2009). Consequences of postpurchase dissonance: The mediating role of an external information search. Social Behavior And Personality: An International Journal, 37(10), 1327-1339.

Kim, S.-H., \& Shanahan, J. (2003). Stigmatizing smokers: Public sentiment toward cigarette smoking and its relationship to smoking behaviors. Journal of Health Communication, 8(4), 343-367.

Koch, E. J. (2014). How does anticipated regret influence health and safety decisions? A literature review. Basic and Applied Social Psychology, 36(5), 397-412.

Lancellotti, M. P., \& Thomas, S. (2018). Men hate it, women love it: Guilty pleasure advertising messages. Journal of Business Research, 85, 271-280.

Landman, J. (1993). Regret: The persistence of the possible. Oxford University Press.

Lazuras, L., Chatzipolychroni, E., Rodafinos, A., \& Eiser, J. R. (2012). Social cognitive predictors of smoking cessation intentions among smoker employees: The roles of anticipated regret and social norms. Addictive Behaviors, 37(3), 339-341.

Lee, S. H., \& Cotte, J. (2009). Post-purchase consumer regret: Conceptualization and development of the PPCR scale. ACR North American Advances.

Lee, W. B. (2007). Rationalization and Regret among Smokers in Thailand and Malaysia. A thesis presented to the University of Waterloo in fulfilment of the thesis requirement for the degree of Doctor of Philosophy in Psychology. Waterloo, Ontario, Canada.

Lee, J., Jung, S., Kim, J. W., \& Biocca, F. (2019). Applying Spatial Augmented Reality to Anti-Smoking Message: Focusing on Spatial Presence, Negative Emotions, and Threat Appraisal. International Journal of Human-Computer Interaction, 35(9), 751-760.

Lemaster, P. C. (2010). When "What Tastes Right" Feels Wrong: Guilt, Shame, and Fast Food Consumption, Doctoral dissertation, Marietta College.

Lerbin, R. A. R. (2015). Attitude as a Mediator between Cognitive Dissonance and Intention to Repurchase a Product. Mediterranean Journal of Social Sciences, 6(5), 133.
Lerman, C., Caporaso, N. E., Audrain, J., Main, D., Bowman, E. D., Lockshin, B., Shields, P. G. (1999). Evidence suggesting the role of specific genetic factors in cigarette smoking. Health Psychology, 18(1), 14.

Lickel, B., Kushlev, K., Savalei, V., Matta, S., \& Schmader, T. (2014). Shame and the motivation to change the self. Emotion, 14, 1049-1061.

Lyons, S. J., Wien, A. H., \& Altintzoglou, T. (2019). Guilt-free pleasures: how premium and luxury influence regret. Journal of Product \& Brand Management. Vol. 27 Iss 1, 35-44.

Lu, Y., Lu, Y., \& Wang, B. (2012). Effects of dissatisfaction on customer repurchase decisions in e-commerce-an emotion-based perspective. Journal of Electronic Commerce Research, 13(3), 224.

Luchs, M. G., \& Mick, D. G. (2018). Consumer Wisdom: A Theoretical Framework of Five Integrated Facets. Journal of Consumer Psychology. 28(3), 365-392.

Mackinnon, S. P., \& Wang, M. (2020). Response-Order Effects for Self-report Questionnaires: Exploring the role of Overclaiming Accuracy and Bias. Journal of Articles in Support of the Null Hypothesis, 16(2).

Matthes, J. M., \& Ball, A. D. (2019). Discriminant validity assessment in marketing research. International Journal of Market Research, 61(2), 210-222.

Uygur, S. M., \& Küçükergin, K. G. (2013). Fast-Food Restoranlarda Bireysellestirme, Müsteri Tatmini, Minnettarlik ve Tekrar Satin Alma Egilimi Arasindaki Iliski: Tekrar Satin Alma Egiliminde Ataletin Farklilastirici Etkisi/The Relationship Between Customization, Customer Satisfaction, Gratitude and Repurchase Intention in The Fast Food Restaurants: The Moderating Effect of Inertia on Repurchase Intention. Ege Akademik Bakis, 13(3), 383.

Metin, I., \& Camgoz, S. M. (2011). The advances in the history of cognitive dissonance theory. International Journal of Humanities and Social Science, 1(6), 131-136.

Moan, I. S., \& Rise, J. (2005). Quitting Smoking: Applying an Extended Version of the Theory of PlannedBehavior to Predict Intention and Behavior. Journal of Applied Biobehavioral Research, 10(1), 39-68.

Moore, D. S., Notz, W. I, \& Flinger, M. A. (2013). The basic practice of statistics (6th ed.). New York, NY: W. H. Freeman and Company. Page (138).

Namkoong, K., Nah, S., Record, R. A., \& Van Stee, S. K. (2017). Communication, reasoning, and planned behaviors: unveiling the effect of interactive communication in an anti-smoking social media campaign. Health communication, 32(1), 41-50.

Naslund, J. A., Kim, S. J., Aschbrenner, K. A., McCulloch, L. J., Brunette, M. F., Dallery, J., Bartels J.S. \& Marsch, L. A. (2017). Systematic review of social media interventions for smoking cessation. Addictive behaviors, 73, 81-93. 
Nayak, P., Salazar, L. F., Kota, K. K., \& Pechacek, T. F. (2017). Prevalence of use and perceptions of risk of novel and other alternative tobacco products among sexual minority adults: Results from an online national survey, 2014-2015. Preventive Medicine, 104, 71-78.

Netemeyer, R. G., Burton, S., Andrews, J. C., \& Kees, J. (2016). Graphic health warnings on cigarette packages: the role of emotions in affecting adolescent smoking consideration and secondhand smoke beliefs. Journal of Public Policy \& Marketing, 35(1), 124-143.

OECD Health Statistics, (2019), Health at a Glance 2019: OECD Indicators, https://www.oecd-ilibrary.org/sites/d7884747en/index.html?itemld=/content/component/d7884747-en

Orcullo, D. J. C., \& San, T. H. (2016). Understanding cognitive dissonance in smoking behaviour: A qualitative study. International Journal of Social Science and Humanity, 6(6), 481.

Ozcan, S., Tas, H. Y., \& Cetin, Y. (2013). Sigara İle Mücadelede Toplumsal Bilinç. Hak Iş Uluslararası Emek ve Toplum Dergisi, 2(4).

Ozbas, S., Onur, R., \& Alkan, M. A. (2018). Behavior and attitudes towards smoking among teachers in Turkey. Journal of Public Health, 1-9.

Passyn, K., \& Sujan, M. (2006). Self-accountability emotions and fear appeals: Motivating behavior. Journal of Consumer Research, 32(4), 583-589.

Patrick, V. M., Lancellotti, M., \& Hagtvedt, H. (2009). Getting a second chance: the role of imagery in the influence of inaction regret on behavioral intent. Journal of the Academy of Marketing Science, 37(2), 181-190.

Patten, C. A., Lando, H., Resnicow, K., Decker, P. A., Smith, C. M., Hanza, M. M., Burhansstipanov L., \& Scott, M. (2018). Developing health communication messaging for a social marketing campaign to reduce tobacco use in pregnancy among Alaska native women. Journal of Communication in Healthcare, 11(4), 252-262.

Penz, E., \& Hogg, M. K. (2011). The role of mixed emotions in consumer behaviour: Investigating ambivalence in consumers' experiences of approach-avoidance conflicts in online and offline settings. European Journal of Marketing, 45(1/2), 104-132.

Pham, T., Ha, T., \& Soulakova, J. N. (2019). Design-based single-mediator approach for complex survey data. Communications in Statistics-Simulation and Computation, 1-10.

Poutvaara, P., \& Siemers, L.-H. (2008). Smoking and social interaction. Journal of Health Economics, 27(6), 1503-1515.

Preacher, K. J., \& Hayes, A. F. (2008). Asymptotic and resampling strategies for assessing and comparing indirect effects in multiple mediator models. Behavior research methods, 40(3), 879-891.

Ra, J. S., \& Cho, Y. H. (2018). Role of social normative beliefs as a moderating factor in smoking intention among adolescent girls in Korea. Nursing \& health sciences, 20(4), 530-536.
Rahman, M. S., Mannan, M., \& Rahman, M. M. (2018). The intention to quit smoking: The impact of susceptibility, self-efficacy, social norms and emotional intelligence embedded model. Health Education, 118(1), 96-110.

Raza, S. H., Zia, A., \& Iftihkar, M. (2018). Interplay of Direct Anti-Smoking Public Service Advertisements and Anti-Smoking Messages Placement Disclosures in Movies with Attitude to Quit Smoking. Global Social Sciences Review, 3(3), 332-353.

Reutter, K. K., \& Bigatti, S. M. (2014). Religiosity and spirituality as resiliency resources: Moderation, mediation, or moderated mediation?. Journal for the scientific study of religion, 53(1), 56-72.

Saintives, C., \& Lunardo, R. (2017). When the Service Experience Drives Negative and Positive Emotions: The Moderating Role of Pride in the Effects of Guilt on Coping and Satisfaction: An Abstract. Paper presented at the Academy of Marketing Science Annual Conference.

Sampogna, G., Bakolis, I., Evans-Lacko, S., Robinson, E., Thornicroft, G., \& Henderson, C. (2017). The impact of social marketing campaigns on reducing mental health stigma: results from the 2009-2014 Time to Change programme. European Psychiatry, 40, 116-122.

Sandberg, T., Hutter, R., Richetin, J., \& Conner, M. (2016). Testing the role of action and inaction anticipated regret on intentions and behaviour. British Journal of Social Psychology, 55(3), 407-425.

Sansone, G., Fong, G. T., Hall, P. A., Guignard, R., Beck, F., Mons, U., Pötschke-Langer M., Yong H.-H., Thompson M. E., Omar, M. (2013). Time perspective as a predictor of smoking status: Findings from the International Tobacco Control (ITC) Surveys in Scotland, France, Germany, China, and Malaysia. BMC Public Health, 13(1), 346.

Schermelleh-Engel, K., Moosbrugger, H., \& Müller, H. (2003). Evaluating the fit of structural equation models: Tests of significance and descriptive goodness-of-fit measures. Methods of psychological research online, 8(2), 23-74.

Segars, A. H., \& Grover, V. (1993). Re-examining perceived ease of use and usefulness: A confirmatory factor analysis. MIS quarterly, 517-525.

Shiffman, S., \& Paty, J. (2006). Smoking patterns and dependence: contrasting chippers and heavy smokers. Journal of Abnormal Psychology, 115(3), 509.

Steenhaut, S., \& Van Kenhove, P. (2006). An empirical investigation of the relationships among a consumer's personal values, ethical ideology and ethical beliefs. Journal of Business Ethics, 64(2), 137-155.

Sweeney, J. C., Hausknecht, D., \& Soutar, G. N. (2000). Cognitive dissonance after purchase: A multidimensional scale. Psychology and Marketing, 17(5), 369-385.

Tabachnick, B. G. And Fidell, L. S. (2013). Using multivariate statistics. Boston, Pearson. 
Terry-McElrath, Y. M., Emery, S., Wakefield, M. A., O'Malley, P. M., Szczypka, G., \& Johnston, L. D. (2013). Effects of tobacco-related media campaigns on smoking among 20-30-year-old adults: longitudinal data from the USA. Tobacco control, 22(1), 38-45.

The World Health Organisation (WHO) report on the global tobacco epidemic (2019), Country profile Turkey, https:// www.who.int/tobacco/surveillance/policy/country_profile/tur.pdf

The World Bank (2019). Stop Smoking It's Deadly and Bad For The Economy, Global Tobacco Control, https://www. worldbank.org/en/topic/tobacco

Turkish Ministry of Health (2018), https://dosyasb.saglik.gov. tr/Eklenti/36134,siy2018trpdf.pdf?0

Tongco, M. D. C. (2007). Purposive sampling as a tool for informant selection. Ethnobotany Research and applications, 5, 147-158.

Tracy, J. L., \& Robins, R. W. (2007). The self in self-conscious emotions: A cognitive appraisal approach. The self-conscious emotions: Theory and research, 3-20.

Tsiros, M., \& Mittal, V. (2000). Regret: A model of its antecedents and consequences in consumer decision making. Journal of Consumer Research, 26(4), 401-417.

Uğur, A., \& Kömürcüler, E. (2015). Türkiye'de Sigara'nin Vergilendirilmesinin Etkinliği. Suleyman Demirel University The Journal of Faculty of Economics and Administrative Sciences, 20(4), 327-346.

Uzundumlu, A. S., \& Topcu, Y. (2015). Determination of Factors Impacting Smoking Habits of University Students: An Empirical Analysis from Turkey. Studies On Ethno-Medicine, 9(3), 279-287.

Ünal, S., Deniz, E., \& Akin, N. (2019). Determining the Factors That Influence the Intention to Purchase Luxury Fashion Brands of Young Consumers. Ege Academic Review, 19(2).
Yang, D. J. (2018). Exploring the communication effects of message framing of smoking cessation advertising on smokers'mental processes. International Review on Public and Nonprofit Marketing, 15(3), 315-332.

Yoo, W., Yang, J., \& Cho, E. (2016). How social media influence college students' smoking attitudes and intentions. Computers in Human Behavior, 64, 173-182.

Yoo, S. C., \& Eastin, M. S. (2017). Designing Health Games for Anti-Smoking Advertising Targeting College Students: The Impact of Message Types and Voice-Over. International Journal of Contents, 13(3).

Wagner, U., Handke, L., Dörfel, D., \& Walter, H. (2012). An experimental decision-making paradigm to distinguish guilt and regret and their self-regulating function via loss averse choice behavior. Frontiers in psychology, 3, 431.

Williamson, T. J., Kwon, D. M., Riley, K. E., Shen, M. J., Hamann, H. A., \& Ostroff, J. S. (2020). Lung Cancer Stigma: Does Smoking History Matter?.Annals ofBehavioralMedicine. 1-6

Wymer, W. (2015). Formulating effective social marketing and public health communication strategies. In Innovations in Social Marketing and Public Health Communication, 3-31. Springer, Cham.

Wymer, W. (2017). Social marketing strategy and industry involvement. Journal of Social Marketing, 7(3), 297-304.

Wong, K. F. E., \& Kwong, J. Y. (2007). The role of anticipated regret in escalation of commitment. Journal of Applied Psychology, 92(2), 545.

Zeelenberg, M., \& Breugelmans, S. M. (2008). The role of interpersonal harm in distinguishing regret from guilt. Emotion, 8(5), 589. 


\section{APPENDIX}

The items later added to the model (FIN4, FIN8, FIN10, HEA4, MOR7-MOR13) are shown with "**

The reverse coded is shown with "®"

\section{Scales of The Study}

\section{Financial Guilt=FINANCE}

FIN1 I sometimes feel guilty when I buy tobacco/smoke, although I do not want to do so.

FIN2 I feel guilty due to the impact of buying tobacco/smoking on my financial status.

FIN3 I do not feel bad when I buy tobacco, although the others see buying tobacco/smoking as a waste. ${ }^{\circledR}$

*FIN4 I feel guilty when I spend money on smoking instead of buying my needs.

FIN5 Although I do not approve buying tobacco/smoking, I do not feel regret when I buy ${ }^{\circledR}$

FIN6 | feel guilty when I buy an expensive brand of tobacco.

FIN7 I want to return the tobacco I purchased since I feel financially guilty.

*FIN8 I do not regret buying tobacco as I thought I make contribution to the national economy.

FIN9 I feel regret buying tobacco when I think that smoking prevents me from saving money.

*FIN10 Although I know that it affects the household budget adversely; I do not regret buying tobacco.

FIN11 I do not feel regret, even if buying tobacco turns into an unplanned purchase ${ }^{\oplus}$

FIN12 I feel regret when I do not buy the tobacco of optimal quality relative to its price.

\section{Health Guilt=HEALTH}

HEA1 As I know smoking is harmful for my health, I feel regret when I smoke/buy tobacco.

HEA2 Since smoking restricts my body movements (inability to climb up stairs, inability to run etc.), I feel regret when I smoke/ buy tobacco.

HEA3 Since tobacco contain many harmful substances, I feel regret when I smoke/buy tobacco.

HEA4 I still continue smoking although I am aware of its harmful effects on the health of my family, especially my children.

*HEA5 I feel more regret than non-smokers when I do not undergo my annual routine health checks.

HEA6 | feel concerned over my health when I smoke too much.

HEA7 | feel concerned over my health every time I smoke/buy tobacco.

\section{Moral Guilt=MORAL}

MOR1 If I think smoking is against my beliefs, I do not smoke/buy tobacco.

MOR2 I do not smoke/buy tobacco when I think smoking is morally wrong.

MOR3 I do not feel bad when I smoke/buy tobacco even if smoking is against my beliefs. ${ }^{\circledR}$

MOR4 I feel regret smoking when I think that smoking is condemned by the society.

MOR5 Even if smoking is against my moral values, it does not influence my decisions on smoking/buying tobacco ${ }^{\oplus}$

MOR6 I do not smoke/buy tobacco when I think smoking is not right.

*MOR7 | feel guilty when I think that I am harming my family, friends and other people around me.

*MOR8 I feel guilty when I think that I am harming myself while smoking

*MOR9I feel guilty when I think that my hair, clothes and breath smell bad after smoking.

*MOR10The legal regulations imposed to ban smoking in certain areas make me feel guilty.

*MOR11 I feel guiltier when I see the anti-smoking public service ads on the TV.

*MOR12 I feel guiltier when I watch TV shows about the harmful effects of smoking.

*MOR13 Images on cigarette packages make me feel guilty.

\section{Social Responsibility Guilt=SOCIAL}

SOS1 When I think of the damage that cigarette gives to nature, I feel bad for everyone else.

SOS2 I feel guilty when my family feels sorry for my smoking

SOS3 I feel guilty about running away from organizations about smoking cessation. 
SOS4 I do not feel guilty to anyone because I smoke.

\section{Consumer Regret=REGRET}

REG1 I feel bad when I smoke/buy tobacco.

REG2 | feel regret after I smoke/buy tobacco.

REG3 Sometimes I think it would be better in every aspect to buy another thing instead of tobacco.

\section{Repurchase Intention=REPURCHA}

REP1 Despite its negative effects, I still buy tobacco when I need to.

REP2 Despite everything, I still give priority to buying tobacco over other goods.

REP3 Despite everything, I will continue buying tobacco as I know I will be happy.

REP4 Despite everything, I still intend to continue smoking/buying tobacco.

REP5 I do not buy any other thing to substitute when I cannot find any tobacco.

\section{Attitudes=ATTITUDE}

ATT1 Despite their negative effect, smoking gives me pleasure.

ATT2 Despite everything, smoking still makes me psychologically relieved.

ATT3 I like smoking despite its harmful effects.

ATT4 Despite everything, I feel like I am having a good time when I smoke.

ATT5 Smoking makes me happy. 